\title{
\begin{tabular}{l|l|l} 
& Jurnal Kependidikan Dasar & Volume : \\
& Nomor :2 \\
Islam Berbasis Sains & Tahun : 2018 \\
\hline
\end{tabular}
}

\section{Pemahaman Penggunaan Ejaan Terhadap Kemampuan Menulis Karangan Siswa Sekolah Dasar}

\author{
Windhi Pangestu Rini, dan Sutrisno Sahari \\ PGSD UNP Kediri \\ Surel : novisanti@unpkediri.ac.id
}

\begin{abstract}
ABSTRAK
Pokok permasalahan dalam penelitian ini adalah keterkaitan antara pemahaman penggunaan ejaan pada penulisan karangan siswa kelas V SDN Selodono. Penelitian ini bertujuan untuk mendeskripsikan tingkat pemahaman penggunaan ejaan pada karangan siswa kelas V SDN Selodono Kecamatan Ringinrejo Kabupaten Kediri. Penelitian ini menggunakan pendekatan kualitatif jenis deskriptif dengan subjek penelitian siswa kelas V SDN Selodono sebanyak 36 siswa. Instrumen pengumpulan data dengan menggunakan human instrument atau peneliti itu sendiri. Pengumpulan data dalam penelitian ini menggunakan teknik simak dan catat. Tahap selanjutnya adalah pemberian skor untuk mengukur tingkat pemahaman penggunaan ejaan siswa. Berdasarkan hasil penelitian diperoleh data sebagai berikut: 1) kategori kurang paham (skor <70) sebesar $69,44 \%$ yang berarti sebanyak 25 siswa dari total 36 siswa berada pada kategorisasi kurang paham; 2) kategori cukup paham (skor 70-79) adalah sebesar 13,88\% yang berarti sebanyak 5 siswa dari total 36 siswa berada pada kategorisasi cukup paham; 3) kategori paham (skor 80-89) adalah sebesar 13,88\% yang berarti sebanyak 5 siswa dari total 36 siswa berada pada kategorisasi paham; dan 4) kategori sangat paham (skor 90-100) sebesar 2,77\% yang berarti sebanyak 1 siswa dari total 36 siswa berada pada kategorisasi sangat paham. Berdasarkan simpulan hasil penelitian ini, tingkat pemahaman penggunaan ejaan pada karangan masih rendah. Dengan demikian, disarakan bagi guru untuk memberikan contoh penggunaan ejaan bagi siswa baik secara lisan maupun tertulis dalam pembelajaran.
\end{abstract}

Kata kunci: karangan, ejaan.

Abstract

The main problem in this study is the relationship between understanding the use of spelling in writing essays of fifth grade students of Selodono Elementary School. This study aims to describe the level of understanding the use of spelling in the essays of fifth grade students of Selodono Elementary School, Ringinrejo District, Kediri Regency. This study used a descriptive qualitative approach with 36 students of the fifth grade students of Selodono Elementary School. Data collection instruments using human instruments or the researchers themselves. Collecting data in this study uses techniques to see and note. The next stage is the provision of scores to measure the level of understanding of student spelling use. Based on the results of the study obtained the following data: 1) the category of poor understanding (score $<70$ ) amounted to $69.44 \%$ which 
means that as many as 25 students out of a total of 36 students in the category do not understand; 2 ) the category of understanding enough (score 70-79) is $13.88 \%$ which means that as many as 5 students from a total of 36 students are categorized as quite understanding; 3) the understanding category (score $80-89$ ) is $13.88 \%$ which means that as many as 5 students from a total of 36 students are in the category of understanding; and 4) very understandable categories (score 90100) of $2.77 \%$, which means that 1 student out of a total of 36 students is in the category very well understood. Based on the conclusions of the results of this study, the level of understanding the use of spelling in essays is still low. Thus, it is recommended for teachers to provide examples of the use of spelling for students both verbally and in writing in learning.

Keyword : Essay, spelling

\section{A. Pendahuluan}

Pembelajaran Bahasa Indonesia merupakan mata pelajaran yang penting dan diberikan pada seluruh jenjang pendidikan dari tingkat sekolah dasar hingga perguruan tinggi. Pada masingmasing jenjang ini memiliki tujuan yang berbeda satu dengan yang lain.

Kemampuan

berbahasa

berpangaruh terhadap kemampuan konstruksi berpikir. Menurut Sofwan, kemampuan berbahasa mempunyai pengaruh terhadap pembelajaran matematika. ${ }^{1}$ Karena kemampuan siswa dalam memahami suatu mapel bermula dari kemampuan membaca dan menulis. Kemampuan menulis merupakan kemampuan yang sebaiknya dimiliki oleh siswa karena ada mempengaruhi proses konstruksi pengetahuan. Sehingga peran guru bahasa Indonesia terutama untuk anak usia sekolah dasar sangat penting.

Pembelajaran Bahasa Indonesia wajib diikuti oleh semua siswa di sekolah dasar dan bertujuan untuk meningkatkan kemampuan siswa dalam berkomunikasi dengan bahasa Indonesia baik secara lisan maupun tulisan.

\footnotetext{
${ }^{1}$ Sofwan Hadi, "Proses Konstruksi Pengetahuan Siswa Pada Pembelajaran Perbandingan Trigonometri” (Universitas Negeri Malang, 2008).
}

Kemampuan mengajarkan menulis perlu dimiliki oleh guru. Menurut Novy, diera sekarang kemampuan menulis sangat diperlukan. ${ }^{2}$ Sehingga pembelajaran yang berbasis menulis perlu dilakukan oleh guru. Terutama untuk usia sekolah dasar yang merupakan tahapan pertama dalam belajar.

Salah satu materi pembelajaran Bahasa Indonesia di sekolah dasar yang dapat meningkatkan keterampilan berkomunikasi secara tulisan adalah menulis karangan. Menurut Kosasih, E, "Karangan adalah bentuk tulisan yang mengungkapkan pikiran dan perasaan pengarang dalam satu kesatuan tema yang utuh". ${ }^{3}$ Dengan demikian, karangan merupakan pengungkapan sebuah gagasan atau ide berdasarkan tema yang dituangkan dalam bentuk serangkaian kalimat sehingga membentuk suatu paragraf atau alinea.

\footnotetext{
${ }^{2}$ Erwin Putera Permana dkk., "Pelatihan Penulisan Karya Ilmiah Untuk Guru Sekolah Dasar Pada Anggota Gugus 1 Kecamatan Ringinrejo Kabupaten Kediri," Jurnal ABDINUS: Jurnal Pengabdian Nusantara 1, no. 1 (2017): 53-68.

${ }^{3}$ Engkos Kosasih, Kompetensi ketatabahasaan dan kesusastraan: cermat berbahasa Indonesia (Bandung: Yrama Widya, 2003), 9.
} 
Dalam menulis karangan diperlukan modal dasar mengarang agar menghasilkan karangan yang baik. Salah satu syarat yang harus dikuasai siswa dalam menulis karangan adalah pemahaman siswa tentang penggunaan ejaan pada karangan. Menurut Nanik, "Ejaan didefinisikan sebagai kaidahkaidah cara menggambarkan bunyibunyi (kata, kalimat, dan sebagainya) dalam bentuk tulisan (huruf-huruf) serta penggunaan tanda baca".4 Dengan demikian, ejaan berkaitan dengan keseluruhan sistem dan peraturan penulisan bunyi bahasa yang meliputi kata, kalimat dan sebagainya dalam bentuk tulisan serta penggunaan tanda baca sebagai sarananya.

Namun

kenyataannya kemampuan menulis karangan siswa kelas V SDN Selodono masih rendah. Hal tersebut disebabkan karena rendahnya pemahaman siswa terkait kaidah penggunaan ejaan pada karangan yang mencakup kaidah penulisan huruf kapital; kaidah penulisan kata yang meliputi kata depan (di, ke, dan dari), partikel -pun, angka dan bilangan, kata ganti (-ku, -kau, -mu, -nya); dan penulisan tanda baca (titik, koma, hubung, titik dua). Pemahaman siswa yang rendah bisa diakibatkan oleh bantuan guru yang kurang. Menurut Sofwan, bantuan yang diperlukan oleh guru dalam pembelajaran harus cukup dan tidak berlebihan. ${ }^{5}$ Sehingga guru harus

\footnotetext{
${ }^{4}$ Niknik M. Kuntarto, Cermat dalam Berbahasa Teliti dalam Berpikir (Jakarta, 2007), 155.

5 Sofwan Hadi, "Scaffolding dalam Menyelesaikan Permasalahan KPK dan FPB," Ibriez: Jurnal Kependidikan Dasar Islam Berbasis Sains 1, no. 1 (2016): 141-148.
}

mehami dengan baik konsep yang ingin dijelaskan agar dapat memebrikan bantuan yang cukup kepada siswa.

Kondisi lain yang menyebabkan rendahnya pemahaman siswa dalam menulis karangan adalah kurangnya sentuhan guru dalam memberikan berbagai strategi menulis yang tepat. Guru tidak mengajarkan langkah-langkah menulis karangan yang baik dan benar dengan memperhatikan penggunaan ejaan pada karangan, sehingga siswa menulis karangan sesuai dengan pengetahuan dan keinginan mereka tanpa memperhatikan aturan.

Dengan demikian, penelitian ini dilakukan untuk mengetahui tingkat pemahaman penggunaan ejaan pada karangan siswa kelas V SDN Selodono.

Berdasarkan uraian tersebut dipilihlah judul penelitian: "Pemahaman Penggunaan Ejaan pada Karangan Terhadap Kemampuan Menulis Karangan Siswa Kelas V SDN Selodono Kecamatan Ringinrejo Kabupaten Kediri Tahun 2016/2017".

\section{B. Metode Penelitian}

Pendekatan yang digunakan dalam penelitian ini adalah pendekatan kualitatif dengan jenis penelitian deskriptif yaitu suatu pendekatan penelitian yang akan menghasilkan data deskripsi berupa kata-kata baik lisan maupun tertulis dan bukan berupa angka. Pendekatan ini bertujuan untuk menggambarkan dan menginterpretasi objek sesuai apa adanya. Pada penelitian ini penelitian dilakukan dengan memberikan istrumen mengarang siswa. 
Hasil pekerjaan siswa dianalisis dengan deskriptif untuk melihat sejauhmana kemampuan menulis. Pada tahapan peneliti merupakan instrumen penting dalam penelitian. ${ }^{6}$

Penelitian ini dilaksanakan di kelas V SDN Selodono dengan 36 sumber data. Teknik pengumpulan data yang digunakan dalam penelitian ini adalah teknik simak yang mana teknik ini digunakan untuk menyimak penggunaan bahasa pada karangan khususnya penggunaan ejaan, sedangkan teknik catat digunakan untuk mencatat kesalahan penggunaan bahasa. Setelah mengidentifikasi kesalahan penggunaan ejaan pada karangan, tahap selanjutnya adalah pemberian skor untuk mengukur tingkat pemahaman penggunaan ejaan siswa.

\section{Hasil dan Pembahasan}

Hasil penelitian ini berupa deskripsi tingkat pemahaman penggunaan ejaan pada karangan siswa kelas $\mathrm{V}$ SDN Selodono. Tingkat pemahaman penggunaan ejaan pada karangan siswa dapat dilihat dari jumlah kesalahan yang terdapat pada hasil karangan siswa yang mencakup penggunaan huruf, penulisan kata, dan penggunaan tanda baca.

Berdasarkan hasil penelitian, dipaparkan kesalahan penggunaan huruf kapital pada karangan siswa kelas V SDN Selodono sebanyak 317 kesalahan, kesalahan penulisan kata sebanyak 188 kesalahan, dan kesalahan penggunaan tanda baca sebanyak 174 kesalahan.

\footnotetext{
${ }^{6}$ Lexy J. Moleong, Metodologi Penelitian Kualitatif (Bandung: Remaja Rosda Karya, 1999).
}

Dengan demikian, dapat disimpulkan bahwa pemahaman siswa dalam penulisan huruf kapital pada karangan menjadi tingkatan paling rendah yang dikuasai siswa karena jumlah kesalahan siswa terbanyak terdapat pada penulisan huruf kapital. Sedangkan jumlah kesalahan yang sedikit dilakukan siswa adalah penggunaan tanda baca.

Pemahaman siswa tentang penggunaan ejaan akan berpengaruh pada karangan yang dihasilkan. Siswa dikatakan dapat menulis karangan dengan baik apabila dapat menerapkan kaidah-kaidah penggunaan ejaan pada karangan dengan benar. Dengan demikian untuk mengukur tingkat pemahaman penggunaan ejaan pada karangan siwa maka dilakukan pemberian skor yang beracuan pada jumlah kesalahan yang ditemukan. Adapun teknik pemberian skor dengan menggunakan rumus:

Skor $=\frac{\text { jumlah skor yang diperoleh }}{\text { skor maksimal }} \times 100$

Skor yang diperoleh kemudian dikelompokkan menjadi 4 kategori tingkat pemahaman yaitu:

a. Sangat paham (skor 90-100)

b. Paham (skor 80-89)

c. Cukup paham (skor 70-79)

d. Kurang paham $($ skor $<70)$

Berdasarkan teknik pemberian skor dan kategorisasi di atas, dapat diidentifikasi presentase pemahaman penggunaan ejaan pada karangan siswa kelas V SDN Selodono sebagai berikut.: 1) kategori kurang paham (skor <70) menempati presentase paling besar dari 4 kategori pemahaman tentang 
penggunaan ejaan pada karangan yaitu sebesar 69,44\% yang berarti sebanyak 25 siswa dari total 36 siswa berada pada kategorisasi kurang paham; 2) kategori cukup paham (skor 70-79) adalah sebesar $13,88 \%$ yang berarti sebanyak 5 siswa dari total 36 siswa berada pada kategorisasi cukup paham; 3) kategori paham (skor 80-89) adalah sebesar $13,88 \%$ yang berarti sebanyak 5 siswa dari total 36 siswa berada pada kategorisasi paham; dan 4) kategori sangat paham (skor 90-100) menempati presentase paling sedikit dari 4 kategori pemahaman tentang penggunaan ejaan pada karangan yaitu sebesar 2,77\% yang berarti sebanyak 1 siswa dari total 36 siswa berada pada kategorisasi sangat paham.

Berdasarkan uraian di atas dapat disimpulkan bahwa siswa yang kurang paham menempati urutan teratas sebesar $69,44 \%$ dan hanya terdapat satu siswa yang menempati kategori sangat paham dengan presentase sebanyak 2,77\%. Dapat diartikan bahwa siswa masih belum memahami penggunaan ejaan pada karangan siswa kelas V SDN Selodono Kecamatan Ringinrejo Kabupaten Kediri. Hal tersebut disebabkan faktor internal maupun faktor eksternal. Faktor internal yaitu siswa dan faktor eksternal yaitu guru.

\section{Penutup}

Berdasarkan hasil penelitian dan pembahasan pemahaman penggunaan ejaan pada karangan siswa kelas V SDN Selodono, maka dapat disimpulkan sebagai berikut.
1) kategori kurang paham (skor $<70)$ sebesar 69,44\% yang berarti sebanyak 25 siswa dari total 36 siswa berada pada kategorisasi kurang paham;

2) kategori cukup paham (skor 70-79) adalah sebesar $13,88 \%$ yang berarti sebanyak 5 siswa dari total 36 siswa berada pada kategorisasi cukup paham;

3) kategori paham (skor 80-89) adalah sebesar 13,88\% yang berarti sebanyak 5 siswa dari total 36 siswa berada pada kategorisasi paham; dan

4) kategori sangat paham (skor 90100) sebesar $2,77 \%$ yang berarti sebanyak 1 siswa dari total 36 siswa berada pada kategorisasi sangat paham.

Pemahaman penggunaan ejaan pada karangan siswa sangat berpengaruh pada peran guru, dimana guru bahasa Indonesia berperan sebagai model penggunaan bahasa bagi siswa baik secara lisan maupun tulis. Secara lisan, guru memberikan contoh penggunaan bahasa yang baik dalam menyampaikan materi pembelajaran kepada siswa. Sedangkan secara tertulis, guru memberikan contoh penggunaan bahasa yang baik saat menuliskan materi di papan tulis.

\section{E. Daftar Pustaka}

Hadi, Sofwan. "Scaffolding dalam Menyelesaikan Permasalahan KPK dan FPB." Ibriez: Jurnal Kependidikan Dasar Islam Berbasis Sains 1, no. 1 (2016): 141-148. 
Kosasih, Engkos. Kompetensi

ketatabahasaan dan kesusastraan:

cermat berbahasa Indonesia.

Bandung: Yrama Widya, 2003.

Kuntarto, Niknik M. Cermat dalam

Berbahasa Teliti dalam Berpikir.

Jakarta: Mitra Wacana Media, 2007.

Moleong, Lexy J. Metodologi Penelitian

Kualitatif. Bandung: Remaja Rosda Karya, 1999.

Permana, Erwin Putera, Endang Sri Mujiwati, Sutrisno Sahari, Novi Nitya Santi, Rian Damariswara, Bagus Amirul Mukmin, Farida Nurlaila Zunaidah, Kukuh Andri Aka, dan Karimatus Saidah. "Pelatihan Penulisan Karya Ilmiah Untuk Guru Sekolah Dasar Pada Anggota Gugus 1 Kecamatan Ringinrejo Kabupaten Kediri." Jurnal ABDINUS: Jurnal Pengabdian Nusantara 1, no. 1 (2017): 53-68.

Sofwan Hadi. "Proses Konstruksi

Pengetahuan Siswa Pada

Pembelajaran Perbandingan

Trigonometri." Universitas Negeri Malang, 2008. 